\title{
Intermountain West lightning-caused fires: Climatic predictors of area burned
}

\author{
PAUL A. KNAPP
}

Author is assistant professor, Department of Geography, Georgia State University, Atlanta, Ga. 30303-30383.

\begin{abstract}
An increase in continuous fine fuels promoted by the expansion of aggressive annual exotic grasses in the Intermountain West has altered the region's fire regimes, with both ecologic and economic ramifications. I examine the predictive nature of seasonal climatic variables, seasonal precipitation and temperature data up to 2 years before the actual summer fire season, to forecast the area burned by lightning-caused fires during the 13 fire seasons (1980-1992). Five climatically-distinct regions in the shadscale, sagebrush-steppe, sagebrush-semidesert, and open pine with grass communities of California, Idaho, Nevada, Oregon, and Utah were included in the analysis. The amount of associated variance ranged from 43 to $62 \%$ between area burned and seasonal climatic variables. Results show that the seasonal climate that promotes fire is distinctly regional, even in areas of similar vegetation. However, the area burned increases primarily when the climate favors the growth of annual grasses over perennial species, or promotes either cooler or wetter conditions during the previous summer (fire) seasons. These results provide land managers with additional information for making decisions on presuppression activities.
\end{abstract}

Key Words: annual grasses, cheatgrass, Bromus tectorum, climate, Great Basin, sagebrush

Effective range management in the Intermountain West is, in part, dependent upon the ability to predict the number of fires and the area burned. Natural fire return intervals within the semipristine sagebrush-steppe communities of the Intermountain West range from approximately 32 to 110 years (Wright et al. 1979, Whisenant 1990), but fires are rare (Vale 1982) to non-existent in the shadscale communities (Young and Tipton 1990). The large fire intervals in semipristine areas reflect the lack of continuous fuel to carry the fire across the landscape. The introduction of

The author wishes to thank Kathleen Parker, Henn-Grissino Mayer, Larry Mahuffey, David Engle, and three anonymous revewers for their constructively critical comments. I also wish to thank Borden Dent and Catherine McGovem for editorial assistance, Jeffery McMichael and Melissa Levesque for cartographic production, and Kelly Redmond of the Westem Regional Climate Center and Bill Mitchell of the National Interagency Fire Center for providing the data.

Accepted 17 Jun. 199. exotic annual grasses, however, has led to many areas with $100 \%$ cover (Stewart and Hull 1949) that has substantially increased the likelihood of fire (Hull 1965, Wright 1985). In addition, the dry atmospheric conditions typical of the Intermountain West allow several years accumulation of the grasses without decomposition, and have led to a large increase in the continuity of fine fuels that promote wildfires.

The central focus of rangeland fire control management has been based on sophisticated models such as the National Fire Danger Rating System, the Lightning-Locating and Fire Forecasting System, and the Fire Behavior Prediction System. The National Fire Danger Rating System and Lightning-Locating and Fire Forecasting System models are designed for low resolution/large scale applications, while the Fire Behavior System model is used for high resolution/small scale applications (Bradshaw et al. 1983, Deeming 1983, Latham 1983, Rothermel 1983, Rothermel et al. 1986). These models rely primarily on a variety of weather observations, live and dead fuel moisture values, and in the case of the Fire Behavior Prediction System, topographical features to produce models of fire behavior.

Neither the National Fire Danger Rating System, LightningLocating and Fire Forecasting System, nor the Fire Behavior Prediction System models are designed for long range forecasting. The Lightning-Locating and Fire Forecasting System and Fire Behavior Prediction System are real-time models not designed for predictive application beyond 1 to 2 days, while the National Fire Danger Rating System predicts as well as tracks trends of the fire season for short and medium range (15-30 days) presuppression decisions. National Fire Danger Rating System model outputs are also included for 30 day projections based on the "Severity" system. Some longer range forecasts can be made by examining 1,000 hour ( 40 day) fuel moisture time lags, but these forecasts are viewed as indicative of trends only, and the length of the time lags ( 1,000 hours) does not apply to grassland fuel models (Anderson 1982). More recently, works by Latham and Schlieter (1989) examining ignition probabilities of wildland fuels and McRae (1992) examining the prediction of areas prone to lightning based on geographic factors, have shed additional insight on models used for preseason planning and land use.

Given the long term consequences of altered fire regimes, the ability to predict area burned before the onset of the fire season has become increasingly important to rangeland managers involved in presuppression activities (Phillips and George 1991). The purpose of this paper is twofold: first, to demonstrate that the 
incorporation of seasonal climatic variables, lagged as far back as 2 years before a fire season, can provide a modest degree of long range predictive power as to the likelihood of area burned during the fire season; and second, to discuss the regional differences in the climatic variables that influence fire patterns.

\section{Study Area}

The Intermountain West of the United States is bordered by the Cascade Mountains and Sierra Nevada on the west and Rocky Mountains on the east. The region (approximately $700,000 \mathrm{~km}^{2}$ ) stretches from approximately $38^{\circ}$ to $47^{\circ} \mathrm{N}$. The terrain is classified as basin and range, marked by hundreds of north-south oriented fault-block mountains separated by broad (often $>75 \mathrm{~km}$ wide), flat valleys (Trimble 1989). With the exception of the higher elevations, the climate of the region is classified as semiarid (precipitation totals are 25 to $50 \mathrm{~cm} /$ year) north of $41^{\circ} \mathrm{N}$. Because of the decreased frequency of Pacific type frontal systems, climate conditions get progressively more arid (precipitation totals of 10 to $25 \mathrm{~cm} /$ year) south of $41^{\circ} \mathrm{N}$ (Houghton et al. 1975), and the climate is classified as arid. The region is characterized by strong seasonal temperature variations with extremes of $-40^{\circ}$ to $45^{\circ} \mathrm{C}$ (Western Regional Climate Center 1993).

Three distinct vegetation zones, roughly equal in area, comprise $80 \%$ of the Intermountain West study area (West 1983a, b, c, Trimble 1989). The shadscale [Atriplex confertifolia (Torr.\&Frem.) Wats.] zone represents the lowest elevation and most arid region. Vegetation cover is sparse (typically $<20 \%$ ) with the dominant shrubs being shadsscale, Bailey's greasewood [Sarcabatus baileyi (Cov.) Jeps.], horsebrush (Tetradymis spp.), and the dominant grasses being the perennial Indian ricegrass (Oryzopsis hymenoides ( $\mathrm{R} \& \mathrm{~S}$.) Ricker], and the aggressive exotic annual, cheatgrass (Bromus tectorum L.) (Tueller 1989, Knapp 1992a). The shadscale zone is primarily confined to areas south of $41^{\circ} \mathrm{N}$ and is best represented in the Lahontan and Bonneville basins that lie on the west and east sides of the study area, respectively (West 1983a).

The big sagebrush (Artemisia tridentata Nutt.)-steppe zone occurs under semi-arid conditions primarily north of $41^{\circ} \mathrm{N}$. Cover varies substantially, ranging from $30 \%$ (Knapp 1992a) to over 100\% (Daubenmire 1970). Dominant species are the shrub big sagebrush, the perennial grasses bluebunch wheatgrass [Agropyron spicatum (Pursh.) Scrib. \& Smith], western wheatgrass (A. smithii Rydb.), thickspike wheatgrass [A. dasystachuum (Hook.) Vasey.], needle grasses (Stipa spp.), Idaho fescue (Festuca idahoensis Elmer.), and the annual grasses cheatgrass and medusahead [Taeniatherum caput-medusae (L.) Nevski] (West 1983b, Whitson et al. 1992). In areas receiving minimal anthropogenic disturbance, equal dominance between sagebrush and bunchgrasses typically occurs (West 1983b).

The third zone is the big sagebrush semi-desert. It is found principally south of $41^{\circ} \mathrm{N}$, and although similar to the big sagebrush-steppe zone, is more arid. Additionally, many of the same grasses found in the sagebrush-steppe zone exist, but they comprise less than $30 \%$ of the relative cover while sagebrush is at least $70 \%$ (West 1983c). Absolute cover of higher plants rarely exceeds $40 \%$ (West $1983 \mathrm{c}$ ).

In the more mesic end (typically higher elevations) of the sagebrush-steppe and sagebrush zones, the plant communities may be characterized as grass-dominated (often cheatgrass) with open timber (e.g., ponderosa pine (Pinus ponderosa, Laws), Jeffery pinc ( $P$. Jeffreyi Grev. \& Balf.), and singleleaf pinyon ( $P$ monophylla Torr. \& Frem.). This zone is represented poorly in the Intermountain West, and is not to be confused with singleleaf pinyon and juniper (Juniperus spp.) woodlands that, although are substantially better represented in the Intermountain West, (approximately $82,000 \mathrm{~km}^{2}$ ) are not grass-dominated.

\section{Data and Methods}

Fire statistics were provided by the National Interagency Fire Center (Boise, Ida.). Data for 16 Bureau of Land Management (BLM) districts covered the period 1980 to 1992, and included the annual number of fires and the annual number of acres burned by fuel model classification for both lightning and human-caused fires. Fuel models indicate the type of vegetation that burned. The summed value of lightning-caused fires that burned in the westem annual grass, western perennial grass, open pine with grass, and sagebrush with grass fuel model classifications were used for statistical analyses. Human-caused fires (e.g., accidental fires begun by sparks from catalytic converters or campfires) were excluded. Since population density largely influences the level of human activity and population density varies greatly throughout the study area, the data on human caused fires were eliminated from the models used. The 4 fuel models were grouped together (with annual grasses present in all groups) based on the "GrassDominated Group" classification set forth by Anderson (1982). The fuel model group is characterized by continuous surface of the herbaceous fuel that promotes rapidly moving surface fires. The BLM districts vary substantially in size and in the potential area burned. To make meaningful comparisons then, the area of lightning-caused fires was converted into Z-scores with a mean of 0 and a standard deviation of 1 (SUMLACRE) (Clark and Hosking 1986).

Climatological data were provided by the Western Regional Climate Center (Reno, Nev.). The data set contained monthly precipitation and temperature values of 91 stations within the Intermountain West from 1978 through 1992. All BLM districts were represented climatically by at least 3 stations, and most commonly by 5 or more stations, that fall within the corresponding BLM district boundary. Station data were averaged by BLM district. Seasonal data were then generated by summing the monthly data for each season (using traditional definitions for seasons: e.g., winter-December, January, February; c.f. Knapp 1992b). Because the fire season for the Intermountain West generally occurs from 1 June through 15 September (L. Mahaffey, pers. comm. 1993), all seasons preceding the summer season were included for the previous 2 years (e.g., for the 1992 summer fire season, climatic variables included would be from summer 1990 through spring 1992). Data included both precipitation and temperature, for a total of 16 independent climatic variables (Table 1).

The original $16 \mathrm{BLM}$ districts were combined into 5 regions: the Northwest, represented by the Lakeview, Burns, and Vale (Ore.) districts, and Boise (Ida.) district; the Southwest, represented by the Susanville (Cal.), and Winnemucca and Carson City (Nev.) districts; the Southcentral, comprised of Battle Mountain, Elko, and Ely (Nev.) districts; the Southeast, consisting of the Cedar City, Richfield, and Salt Lake (Ut.) districts; and the Northeast, represented by the Shoshone, Burley, and Idaho 
Table 1. Definitions for independent variables.

\begin{tabular}{|c|c|}
\hline Variable Name & Variable Definition \\
\hline SUMTLAGR & Summer (Jun., Jul., Aug.) temperature lagged 2 seasons \\
\hline AUTTLAG2 & $\begin{array}{l}\text { Autumn (Sep., Oct., Nov.) temperature lagged } 2 \text { sea- } \\
\text { sons }\end{array}$ \\
\hline WINTLAG & Winter (Dec., Jan., Feb.) temperature lagged 1 season \\
\hline SPRTLAG & Spring (Mar., Apr., May) temperature lagged 1 season \\
\hline SUMTLAG & Summer temperature lagged 1 season \\
\hline AUTTLAG & Autumn temperature lagged I season \\
\hline WINT & Winter temperature \\
\hline SPRT & Spring temperature \\
\hline SUMPLAG2 & Summer (Jun., Jul., Aug.) precipitation lagged 2 seasons \\
\hline AUTPLAG2 & Autumn (Sep., Oct., Nov.) precipitation lagged 2 seasons \\
\hline WINPLAG & Winter (Dec., Jan., Feb.) precipitation lagged I season \\
\hline SPRPLAG & Spring (Mar., Apr., May) precipitation lagged I season \\
\hline SUMPLAG & Summer precipitation lagged 1 season \\
\hline AUTPLAG & Autumn precipitation lagged 1 season \\
\hline WINP & Winter precipitation \\
\hline SPRP & Spring precipitation \\
\hline
\end{tabular}

Falls (Idaho) districts (Figure 1). The total area of the districts is approximately 3.15 million $\mathrm{km}^{2}$. The regional groupings were based on 2 climatic criteria that affect vegetation composition. The predominant winter air mass boundary within the Intermountain West, ranging between $40^{\circ} \mathrm{N}$ to $42^{\circ} \mathrm{N}$ from Oregon through Idaho (Mitchell 1976, Woodhouse and Kay 1990) was used to separate the northern and southern regions. The coldest winters are in the Northeast region while the Southwest region has the mildest winters (Table 2). Precipitation patterns, based on amounts and timing, were used to separate the regions further. The Northwest and Southwest regions are both characterized by a winter precipitation maximum; and, the Northeast, Southeast, and Southcentral regions by a spring maximum. The driest region is the Southwest, while the wettest is the

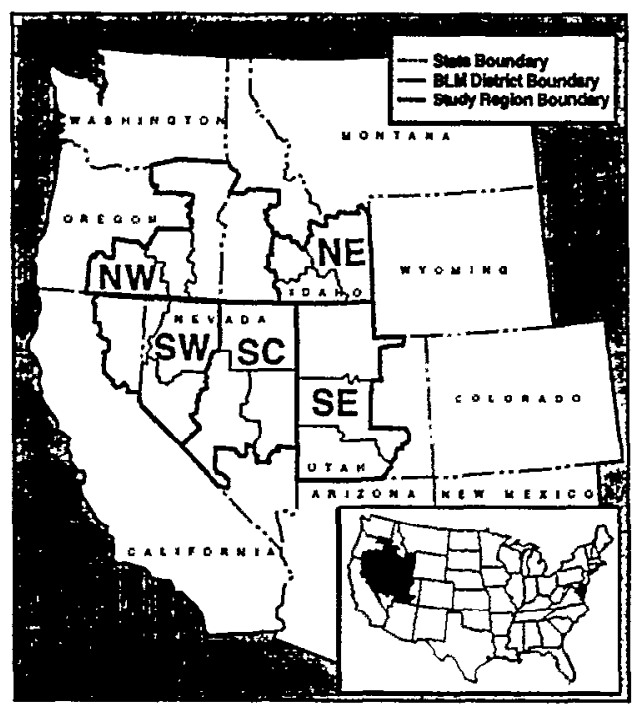

Fig. 1. Location of Intermountain West study regions.
Table 2. Seasonal climate averages for the 5 study regions.'

\begin{tabular}{|c|c|c|c|c|c|}
\hline \multirow{2}{*}{$\begin{array}{l}\text { Seasonal } \\
\text { climate } \\
\text { averages }\end{array}$} & \multicolumn{4}{|c|}{ Region } & \multirow[b]{2}{*}{ Southwest } \\
\hline & Northwest & Northeast & Southeast & Southent. & \\
\hline \multicolumn{2}{|c|}{ Temperature } & \multicolumn{2}{|c|}{$\left({ }^{\circ} \mathrm{C}\right)$} & & \\
\hline Winter & -0.89 & -4.12 & -1.59 & -1.35 & 0.28 \\
\hline Spring & 8.99 & 7.45 & 9.36 & 7.71 & 8.92 \\
\hline Summer & 19.61 & 18.93 & 21.56 & 19.61 & 19.66 \\
\hline Autumn & 9.33 & 7.90 & 10.34 & 9.11 & 9.80 \\
\hline Mean & 9.26 & 7.54 & 9.92 & 8.77 & 9.67 \\
\hline \multicolumn{2}{|c|}{ Precipitation } & \multicolumn{2}{|c|}{$(\mathrm{cm})$} & & \\
\hline Winter & 9.67 & 8.58 & 7.72 & 6.14 & 7.56 \\
\hline Spring & 9.65 & 9.60 & 11.45 & 9.16 & 6.75 \\
\hline Summer & 5.18 & 5.33 & 6.22 & 4.59 & 2.84 \\
\hline Autumn & 7.82 & 7.92 & 10.03 & 6.93 & 6.27 \\
\hline Total & 32.32 & 31.43 & 35.42 & 26.82 & 23.42 \\
\hline
\end{tabular}

'Based on years 1980 through 1992. Source: Westem Regional Climate Center, 1993.

Southeast (Table 2).

Multiple regression analyses were done by region using the annual area burned by lightning-caused fires as the dependent variable. All models were checked for passible violations of the assumptions of the general linear models (Clark and Hosking 1986). Significance of $t$-values and $F$ values were checked, residuals were examined using Cook's $D$ and studentized residuals diagnostics, and the Drubin-Watson test was used to check for autocorrelation. The independent variables were checked for collinearity problems examining condition numbers and variance proportions. Finally, the signs (+ or - ) of the partial regression coefficients were examined to determine if they were logical. None of the models included violated these assumptions (i.e., failed the tests).

\section{Results}

Associated variance $\left(R^{2}\right)$ between lightning-caused fires and climatic variables ranged from 0.43 in the Northwest region to 0.62 in the Southwest region (Table 3). One to 4 independent variables entered into the multiple regression equation.

Regression analyses for the Northwest, Southwest and Southcentral regions showed that a positive SUMPLAG (summer precipitation lagged 1 season) was included in each model, and that the relative contribution of the variable, as shown by the partial coefficient of determination, was substantial for the Northwest and Southcentral regions (Table 3). This indicates that area burned was greater following wet summers the previous year. The Northwest and Southwest regions also included a second common variable, a negative AUTTLAG (autumn temperature lagged 1 year). Autumn temperature lagged 1 year made the greatest contribution to the Northwest model, accounting for approximately one fourth of the total associated variance, but only accounted for approximately one sixth of the total associated variance for the Southwest. This variable suggests that area burned increases following cooler than normal autumns. Minor contributing variables included for the Northwest and Southwest regions were a positive SPRT (spring temperature) and a negative SPRP (spring precipitation), indicating that area burned increases if springtime conditions are warmer and drier than the normal, respectively. A positive SUMPLAG2 (summer precipitation 
Table 3. Regression models for Intermountain West regions predicting area burned as a function of seasonal climatic variability'.

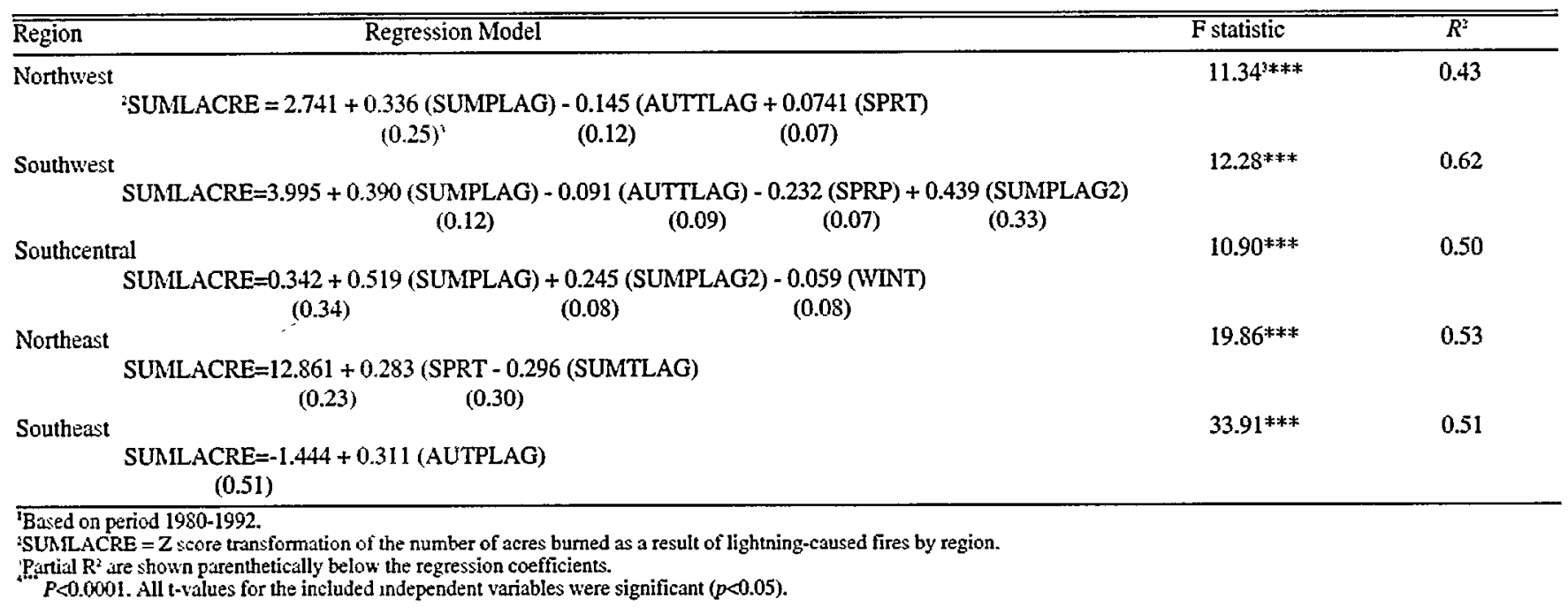

lagged 2 seasons) was common among the Southwest (contributing to over half the total) and Southcentral models and shows that above normal precipitation amounts as far back as 2 years can lead to greater area burned. In addition, a negative WINT (winter temperature) was included in the Southcentral model indicating that below average winter temperatures are followed by more area burned.

Only 3 variables were used for the Northeast and Southeast region regression models. In the Northeast, the relative contribution of the variables was almost evenly distributed between a negative SUMTLAG (summer temperature lagged one season), indicating that below average temperatures the previous summer are associated with greater area burned and above normal spring temperatures. Conversely, the only contribution to the regression model for the Southeast came from a positive AUTPLAG (autumn precipitation lagged one season), which shows that above average autumn precipitation is positively associated with area burned. This correlation may likely be because seedling production of cheatgrass and medusahead is linked to above average autumn rains (West 1983b, Morrow and Stahlman 1984).

Eight of 16 original variables were used by the regression models. Those variables that were not included in the regression models were WINTLAG, SPRTLAG, AUTPLAG, SUMTLAG2, WINPLAG, SPRPLAG, WINP, and AUTTLAG2 (Table 1). Of the 8 variables used, SUMPLAG was found in 3 models; SUMPLAG2, SPRT, and AUTTLAG were found in 2 models; and the remainder of the variables occurred in only 1 model. In general, the regression models for regions with lower annual precipitation included a greater number of significant explanatory variables.

Results of annual fire statistics summed by region and converted into Z-scores show that area burned is highly variable annually, but less variable regionally (Figure 2). In the Northwest, Southwest, and Southcentral regions, the greatest number of acres burned occurred in 1985, while for the Northeast region it was 1992, and for the Southeast, 1983. The years when the least area burned were 1988 for the Northwest and Southeast, 1984 for the Northeast, and 1982 for the Southcentral and Southwest.

Within a region, the number of years with negative Z-scores (showing less area burned) ranged from 7 to 10 , with many of the remaining observations having large $(>0.5)$ positive Z-scóres (Figure 2). These Z-scores show that during this study period, fire seasons in the Intermountain West were not characterized by even distributions of area burned yearly, but rather were marked by many years with little area burned punctuated by the occasional season where the total area burned was large.

\section{Discussion}

The 5 regression models show that a few climatic variables provide a modest degree of associated variance with acres burned by lightning-caused fires, and that seasonal climatic conditions up to 2 years before the fire season may contribute largely to area burned in a given year. These lags indicate that not only are current weather conditions important in determining the likelihood of area burned, but that the area burned is influenced by the magnitude of precipitation and temperature variations in the proceeding months. These climatic fluctuations are important because they influence the amount of fine fuels (cheatgrass and other annual grasses) that promote fires. In Arizona, fire-climate studies in Sonoran Desert vegetation (Rogers and Vint 1987) and mixed conifer and pine forests (Baisan and Swetnam 1990) have shown that fire occurrence is related to above normal precipitation 2 years before the fire season because the wetter conditions produce an abundance of fine fuels necessary to carry fires. Similar interactions between climate, fuel production, and fire intensities exist in the Intermountain West. Interpretation of the regression models for the Intermountain West are based on those climatic variables that tend to either promote more fine fuel production or temporarily suppress fires, which allow greater accumulations and coverage of fine fuels.

\section{Northwest, Southwest, and Southcentral Models}

Common among these models are the contributions of below normal temperatures during either the preceding autumn (AUTTLAG) or winter (WINT) and above normal precipitation the preceding summer (SUMPLAG). Cooler than normal autumns or winters may favor the production of cheatgrass and medusahead for 2 reasons. First, cheatgrass and medusahead may be favored because following the onset of the first autumn rain, growth of 


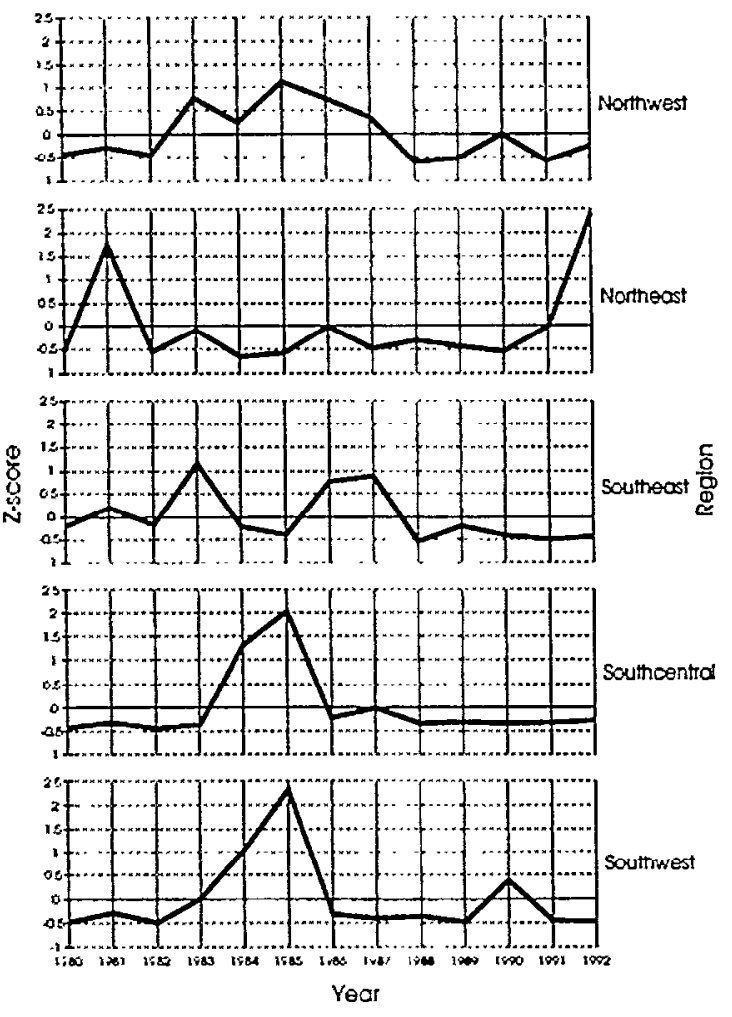

Figure 2. Annual lightning-caused fire statistics by region. The number of acres burned annually as a result of lightning-caused fires were transformed into $Z$-scores with a mean of 0 and standard deviation 1.

their roots can continue as long as temperatures remain above $0^{\circ} \mathrm{C}$. In contrast, native perennial grasses such as Agropyron spicatum cannot grow at temperatures below $4^{\circ} \mathrm{C}$ (Harris 1967 , West $1983 \mathrm{~b}$ ). Second, soil moisture retention is greater during colder winters leading to better spring growth. As a result, the annual grasses are able to establish extensive root systems that ullow them to extract soil moisture at greater rates than the perennial grasses can in the spring when temperatures are sufficiently warm to promote shoot and leaf growth. The net effect is a relative increase in annual cover (Morrow and Stahlman 1984).

Wetter than normal summers the preceding year (and, in the case of the Southwest region, the previous 2 years) promote fire in several ways. Cheatgrass is effective at removing moisture from the upper soil layers and can outcompete many native species such as needleandthread (Stipa comata Trin. \& Rupr.) and green rabbitbrush [Chrysothammus sicidiftrus (Hook.) Nutt.] for the available water resources (Melgoza et al. 1990, Melgoza and Nowak 1991). Because summer rains are short-term conductive thunderstorms that rarely soak the soil, cheatgrass, with its shallow, but extensive root system, is well-equipped to benefit from increased soil moisture following summer precipitation.

Much of the native flora in these regions evolved with mechanisms that conferred particular strategies to cope with drought that are generally not conducive to exploiting summer precipitation. Big sagebrush for example, has a deep root system that allows it to extract water from deep soil layers during the summer and to continue growth after the topsoil becomes dry (Mozingo 1987). However, when summers are wetter than normal, annuals are best able to exploit the short-term favorable soil conditions with an increase in their cover since summer rains rarely soak the soil to the point where perennial species proportionally benefit. The net effect is that because of their high degree of phenotypic plasticity (Young et al. 1972), the normally compressed phenological cycle for cheatgrass and medusahead of drying out and casting seed by early summer (West 1983b) can be expanded to a much later date, with more vegetative growth in the intervening period. The result is an increase in the amount of continuous fine fuel required to carry fire. Finally, wetter summers can increase fuel moisture loads, suppressing fires, and subsequently allowing an even greater continuity of fuels for the following fire season.

The remaining variables included for the Northwest and Southwest regions were warmer spring temperatures (SPRT) and below normal spring precipitation (SPRP), respectively. These variables indicate the importance of reduced fuel moisture levels in the season immediately preceding the summer fire season. Bunting et al. (1987) found that abundant precipitation in late winter and spring raises fuel moistures to the point where fires have difficulty carrying. Either dry or warm spring seasons lead to a more rapid drying stage of the spring annuals, and promote the likelihood of fire early in the season.

\section{Northeast}

Cooler than normal preceding summer temperatures (SUMTLAG) and above normal spring temperatures (SPRT) were linked with increased fire activity in the Northeast region. Above normal spring temperatures in this region promote the likelihood of fire for the same reasons as the Northwest, Southwest, and Southcentral regions. Cooler summer temperatures in the year preceding the fire season tend to decrease the likelihood of fire because of decreased fuel moisture loads, but also lead to greater continuities of fine fuels for the following fire season. Similar conclusions have been found by Balling et al. (1992) in adjacent Yellowstone National Park where they found positive correlations between both antecedent temperatures (January-June) and wildfires (although in forests in contrast to grasslands), and summer temperatures and wildfires

\section{Southeast}

Only one variable, above normal precipitation in the autumn preceding the fire season (AUTPLAG), was included. Above normal autumn precipitation favors the germination and subsequent buildup of annual grasses, particularly $B$. tectorum, that germinate in the fall and establish root systems that provide a competitive advantage to native grasses and shrubs when they resume growth in early spring (Morrow and Stahlman 1984). Consequently, a larger than average amount of continuous fine fuel is produced that increases the chances of fire in the summer season.

\section{Conclusions}

These predictive models using climatic variables indicate that the likelihood of fire is increased by events that promote the growth of fine fuels (i.e., primarily annual grasses), by events that delay or suppress fires, thereby allowing even greater continuities of phytomass, or by a combination of the 2 factors. The models suggest that the timing of seasonal climatic variability that pro- 
motes fire is distinctly regional, even in areas of similar vegetation. They underscore 2 key points: fire area is often increased primarily when either the climatic conditions favor the growth of aggressive, exotic, annual grasses that provide the continuous fine fuels necessary to carry fire, or when these conditions suppress fire long enough to allow sufficient fuel continuity. Additionally, these models are generally in concert with findings of other fire-climate studies in areas bordering the Intermountain West. In studies of the Giant Sequoia groves of the Sierra Nevada (Swetnam 1993) and the Douglas fir [Pseudotsuga menziesii (Mirb.) Franco] and pine (Pinus spp.) forests of the Southwestern United States (Swetnam and Betancourt 1990), it was determined that seasonal climate variability (in addition to fire weather) determines the amount of area burned.

Examining regional similarities and differences sheds considerable insight on the models' usefulness. For the Northwest, Northeast, Southwest, and Southcentral region models, the common characteristic was including either above normal precipitation or below normal temperature during the previous summer seasons. In each of these models, one summer variable contributed over one-half of the total associated variance. The importance of these variables suggests that seasonal climatic conditions affecting fuel moisture (increased precipitation or decreased evaporation) during the summer fire season is particularly important in decreasing the area burned. Additionally, real-time climatic data collection allows for this information to be acquired nine months before the fire season and increases the long range predictive value of the models.

The Southeast region model did not include a summer climate variable. This may be a function of the greater amount and consistency of spring and summer precipitation relative to the other regions. The wetter spring conditions promote abundant herbaceous growth that increases fuel moisture loads. This higher moisture level may make the region less susceptible to lightning ignitions even after the fuels dry, since fires have less success burning through combined live and dead fuels (Bunting et al. 1987).

The predictive power of the models was limited by several factors that undoubtedly influence the occurrence of fire, but were not modeled. These factors include grazing intensity (Higgins 1984), the occurrence of fires outside the summer season, the fact that rarely only one fuel type (e.g., western annual grass only) is found within a region, and time since last fire (since a longer fire interval could allow a greater continuous fuel bed to develop). Favorable fuel conditions may also occur in the absence of lightning ignition.

Given the ecologic and cconomic ramifications (i.e., resource losses, suppression costs, presuppression costs, rehabilitation, and fire management) of increased fire activity there has been an impetus to engage in a variety of fire presuppression activities based on fire danger projections. Increased foot and air patrols, greater emphasis on tracking trends (i.e., projecting out fire probabilities several days in advance), increased fire safety education, and installation of mechanical fire-breaks in areas especially likely to burn are a few presuppression efforts that have been implemented (Pellant 1990, Phillips and George 1991). Prescribed burning is also used as a fire management technique (Bunting et al. 1987). Results from this study suggest that a moderate degree of predictive power can be gained from examining seasonal cli- matic variability up to 2 years before the actual fire season, and could help establish a baseline estimate of area burned in the Intermountain West that could aid in pre-fire season management decisions.

\section{Literature Cited}

Anderson, H.E. 1982. Aids to determining fuel models for estimating fire behavior. USDA Forest Serv. Gen. Tech Rep. INT-122. Ogden, Ut.

Baisan, C.H., and T.W. Swetman. 1990. Fire history on a desert mountain range: Rincon Mountain Wilderness, Arizona, USA Can. J. For. Res. 20:1559-1569.

Balling, R.C., Jr., G.A. Meyer, and S.G. Wells. 1992. Climate change in Yellowstone National Park: Is the drought-related risk of wildfires increasing? Clim. Change 22:35-45.

Bradshaw, L.S., J.E. Deeming, R.E. Burgan, and J.D. Cohen. 1983. The national fire-danger rating system: Technical documentation. USDA Forest Serv. Gen. Tech. Rep. INT-169. Ogden, Ut.

Bunting, S.C., B.M. Kilgore, and C.L. Bushey. 1987. Guidelines for prescribed burning sagebrush-grass rangelands in the northern Great Basin. USDA Forest Serv. Gen. Tech. Rep. INT-231. Ogden, Ut.

Clark, W.A.V., and P.L. Hosking. 1986. Statistical Methods for Geographers. John Wiley and Sons, N.Y.

Daubermire, R. 1970. Steppe vegetation of Washington. Washington Agr. Exp. Sta. Tech. Bull. 62 .

Deeming, J.E. 1983. Reflections on the development, application, and future of the National Fire Danger Rating System, p. 41-44. In: Bradshaw, L.S., J.E. Deeming, R.E. Burgan and J.D. Cohen (eds.), The national fire-danger rating system: Technical documentaion. USDA Gen. Tech. Rep. INT-169. Ogden, Ut.

Harris, G.A. 1967. Some competitive relations between Agropyron spicatum and Bromus tectorum. Ecol. Monog. 37:89-111.

Higgins, K.F. 1984. Lightning fires in North Dakota grasslands and in pinesavanna lands of South Dakota and Montana. J. Range Manage. 37:100103.

Houghton, J.G., C.M.Sakamota, and R.O. Gifford. 1975. Nevada's Weather and Climate. Nevada Bureau of Mines and Geolngy, Reno, Nev.

Hull, A.C. Jr. 1965. Cheatgrass- a persistent homesteader, p. 20-26. In: Anonymous (ed.), Proc. Symposium on management of cheatgrass on rangelands. USDI-BLM, Portland, Ore.

Knapp, P.A. 1992a. Secondary plant succession and vegetation recovery in two westem Great Basin Desert ghost towns. Bio. Conserv. 60:81-89.

Knapp, P.A. 1992b. Correlation of $700 \mathrm{mb}$ height data with seasonal temperature trends in the Great Basin (western USA): 1947-1987. Clim. Res. 2:65-71.

Latham, D.J. 1983. LLAFFS-A lightning locating and fire forecasting system. USDA Forest Serv. Res. Paper INT-315. Ogden, Ut.

Latham, D.J., and J.A. Schlieter. 1989. Ignition probabilities of wildland fuels based on simulated lightning discharges. USDA Forest Serv. Res. Paper INT-411. Ogden, Ut.

McRae, R.H.D. 1992. Prediction of areas prone to lightning ignition. Int. J. Wildland Fire. 2:123-130.

Melgoza, G., Nowak, R.S., and Tausch, R.J. 1990. Soil water exploitation after fire: competition between Bromus tectorum (cheatgrass) and two native species. Oecologia 83:7-13.

Melgoza, G., and R.S. Nowak. 1991. Competition between cheatgrass and two native species after fire: Implications from observations and measurements of root distribution. J. Range Manage. 44:27-33.

Mitchell, V.L. 1976. The regionalization of climate in the western United States. J. App. Meteor. 15:920-927.

Morrow, L.A., and P.W. Stahlman. 1984. The history and distribution of downy brome Bromus tectroum in North America. Weed Sci. Supp. 32:2-6.

Mozingo, H.N. 1987. Shrubs of the Great Basin. University of Nevada Press, Reno, Nev.

Pellant, M. 1990. The cheatgrass-wildfire cycle-Are there any solutions? $p$. 11-18. In: E.D. Mc Arthur, E.M. Romney, S.D. Smith, and P.T. Tueller, (eds.), Proc. - Symposium on cheatgrass invasion, shnub die-off, and other aspects of shrub biology and management, USDA Forest Serv. Gen Tech. Rep. INT-256. Ogden, Ut.

Phillips, C.B., and C.W. George. 1991. Wildland fire in the 1990's: Problems, solutions, and priorities as seen by fire managers. Fire Manage. Notes $52(1): 3-10$. 
Rogers, G.F., and M.K. Vint. 1987. Winter precipitation and fire in the Sonoran Deser. J. Arid Environ. 13:47-52.

Rothermel, R.C. 1983. How to predict the spread and intensity of forest and range fires. USDA Forest Serv. Gen. Tech. Rep. INT-143. Ogden, Ut.

Rothermel, R.C., R.A. Wilson Jr., G.A. Morris, and S.S. Sackett. 1986. Modeling moisture content of fine dead wildland fuels: Input to the BEHAVE fire prediction system. USDA Forest Serv. Gen. Tech. Rep. INT359. Ogden, Ut.

Stewart, G., and A.C. Hull 1949. Cheatgrass (Bromus tectorum L.): An ecologic intruder in southem Idaho. Ecology 30:58-74.

Swetnam, T.W. 1993. Fire history and climate change in Giant Sequoia groves. Sci. 262:885-889.

Swetnam, T.W., and J.L. Betancourt. 1990. Fire-Southern Oscillation relations in the southwestern United States. Sci. 249:1017-1020.

Trimble, S. 1989. The sagebrush ocean. University of Nevada Press, Reno, Nev.

Tueller, P.T. 1989. Vegetation and land use in Nevada. Rangelands 11:204210.

Vale, T.R. 1982. Plants and people: Vegetation change in North America. Assoc. Amer. Geographers, Washington. D.C.

West, N.E. 1983a. Intermountain salt-desert shrubland. p. 375-397, In: N.E. West (ed.) Temperate deserts and semideserts. Elsevier Scientific, Amsterdam.

West, N.E. 1983b. Western intermountain sagebrush steppe. p. 351-374, In: N.E. West (ed.), Temperate deserts and semideserts. Elsevier Scientific, Amsterdam.

West, N.E. 1983c. Great Basin-Colorado Plateau sagebrush semi-desert. p. 331-349, In: N.E. West (ed.), Temperate deserts and semideserts. Elsevier Scientific, Amsterdam.
Western Regional Climate Center. 1993. Monthly precipitation and temperature data: 1940-1992. Desert Research Institute, Reno, Nev.

Whisenant, S.G. 1990. Changing fire frequencies on Idaho's Snake River Plains: Ecological management implications. p. 4-10. In: E.D. McArthur, E.M. Romney, S.D. Smith, and P.T. Tueller, (eds.), Proc.-Symposium on cheatgrass invasion, shrub die-off, and other aspects of shrub biology and management, USDA Forest Serv. Gen. Tech. Rep. INT-256. Ogden, Ut.

Whitson, T.D. (ed.), L.C. Burrill, S.A. Dewey, D.W. Cudney, B.E. Nelson, R.D. Lee, R. Parker. 1992. Weeds of the West. Pioneer, Jackson, Wyo.

Woodhouse, C.A., and P.A. Kay 1990. The use of tree-ring chronologies to show spatial and temporal changes in an air mass boundary. Phys. Geog. 11:172-190.

Wright, H.A. 1985. Effects of fire on grasses and forbs in sagebrush-grass communities, p. 12-21. In: K. Saunders and J. Durham (eds.), Rangeland fire effects-a symposium. Bureau of Land Management, Idaho State Office, Boise, Ida.

Wright, H.A., L.F. Neuenschwander, and C.M. Britton. 1979. The role and use of fire in sagebrush and pinyon-juniper plant communities: a state of the art review. USDA Forest Serv. Gen. Tech. Rep. INT-58. Ogden, Ut.

Young, J.A., R.A. Evans, and J. Major. 1972. Alien plants in the Great Basin. J. Range Manage. 25:194-201.

Young, J.A., and F. Tipton. 1990. Invasion of cheatgrass into arid environments of the Lahontan Basin. p. 37-40. In: E.D. McArthur, E.M. Ronmey, S.D. Smith, and P.T. Tueller, (eds.), Proc.- Symposium on cheatgrass invasion, shrub die-off, and other aspects of shrub biology and management, USDA Forest Serv. Gen. Tech. Rep. INT-256. Ogden, Ut. 